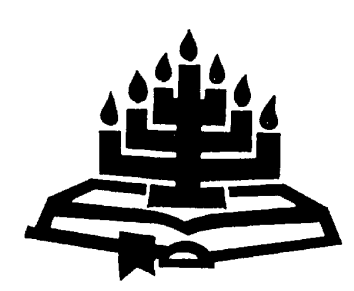

\title{
Vaartversnelling vra verdieping van ons liturgie
}

\author{
B.J. de Klerk \\ Skool vir Kerkwetenskappe \\ Potchefstroomse Universiteit vir CHO \\ POTCHEFSTROOM \\ E-pos: ontbjdk@puknet.puk.ac.za
}

\begin{abstract}
Spurt requests a deepening of our liturgy

The science of Liturgy is currently experiencing a considerable expansion of knowledge and contributions from Reformed scholars need to bear a unique imprint. This article argues for an approach aimed at intensifying the liturgy - an intensification implying that God's mighty presence should be recognized, experienced, acknowledged and confessed in the gathering of the congregation and during each element of the worship service. Two examples, namely the Word service and the service of Humbling and Reconciliation, illustrate what this intensification means. In conclusion, guidelines are provided for addressing contentious liturgical issues, such as transcultural enrichment and the use of symbols and rituals in the liturgy of the congregation and in the liturgy of life.
\end{abstract}

\section{Inleiding}

'n Dramatiese vaartversnelling het die afgelope drie dekades op die vakgebied van die "stiefkind" van die teologiese wetenskap plaasgevind. In 'n sekere sin kan ons praat van Liturgie wat van 'n "stiefkind" tot 'n gewilde "prinses" ontwikkel het. Terwyl op ander vakgebiede van die teologie ernstige wetenskaplike diskussies gevoer is, was die teologie tot ongeveer twintig jaar gelede arm aan diepgaande wetenskaplike navorsing en debatte oor liturgiese aangeleenthede. Daarteenoor, ironies genoeg, was liturgiese kwessies die onmiddelike oorsaak van die mees ingrypende kerklike skeurings en reformasies die afgelope twintig eeue. Vandag is Skrifgebruik, kerksang, die wyse van Nagmaalsviering, die volgorde in die samekomste van die gemeente, ensovoorts, brandpunte (dalk tydbomme) wat van hierdie vakgebied diepgaande en indringende navorsing 
vereis. Op wetenskaplike, kerklike en op die gespreksvlak van lidmate is liturgiese vraagstukke in 'n vaartversnelling. Hoe ons hierdie vaartversnelling kan hanteer, sal tot ' $n$ groot mate medebepaal hoe kerke hulle roeping tot eenheid in Christus en hulle getuienistaak in die wêreld geloofwaardig kan nakom.

Hierdie vaartversnelling vra verdieping van ons liturgie. In hierdie artikel volg ek die volgende metode: eers gaan ek 'n lugfoto van die liturgiese toneel probeer voorhou, 'n beeld waaruit die stroomversnelling hopelik duidelik sal wees, daarna gaan ek 'n nadere aanduiding van 'n eie perspektief op die vinnig groeiende vakgebied aandui, naamlik die noodsaaklikheid van verdieping as 'n unieke bydrae vanuit reformatoriese hoek. Twee voorbeelde sal dien om verdieping in die liturgie te verduidelik. Enkele rigtingwysers hoe om nuwe aktuele vraagstukke vanuit hierdie benadering te beantwoord, sal dan aan die beurt kom.

\section{Die liturgiese toneel vandag}

\section{1 'n Kort snit uit die Afrikaanse vakliteratuur op hierdie vakgebied}

Behalwe talle handboeke en artikels in vakwetenskaplike tydskifte wat die afgelope tien jaar in die buiteland verskyn het (kyk onder andere Lamberts, 1997:442-448; Schmidt-Lauber \& Beiritz, 1995; Schuman \& Oskamp, 1998; Schuman, 1998a), is in Suid-Afrika volledige nommers van Afrikaanse wetenskaplike tydskrifte aan die liturgie gewy (Praktiese Teologie, 1988(6); In die Skriflig, 1989(90) en Koers, 1990(1)). Spoelstra (1994a:117 e.v.) beskryf Vaticanum II (1963) as 'n belangrike draaipunt in die belangstelling in die vakgebied en toon aan dat daar in Europa en geleidelik in Suid-Afrika 'n stroom publikasies verskyn het wat die liturgie plotseling in die brandpunt plaas. 'n Baie belangrike boek in die Reformatoriese tradisie en vanuit Afrikaanse kringe kom uit die pen van Vos en Pieterse (1997). Barnard (1997) benader in sy jongste boek van twee dele die Sondag as feesdag binne die huidige tydsgees in die land. Kritiese, soms moedswillige en dringende vrae word gevra oor vernuwing en verdraagsaamheid op die terrein van die liturgie in twee werke wat onlangs verskyn het (De Klerk, 1998 en König, 1998).

\subsection{Liturgiese bewegings wêreldwyd}

Shepherd (1960:21) skryf: "There is no individual who is competent to give sufficient account of the liturgical renewal in our times". Die liturgiese beweging het wêreldwyd die ervaring van aanbidding van miljoene mense verander. Wat is die liturgiese beweging? Davies (1986:314) beskryf dit as die herontwaking van die kerk. In die negentiende eeu het enkele filosowe God afgeskryf en in die twintigste eeu, met sy twee gruwelike wêreldoorloë, het die Christelike godsdiens in byna alle wêrelddele begin kwyn, behalwe miskien in Afrika en die Ooste. 
Tegelyk kom daar 'n herstel van die liturgie deur die ontdekking van geskrifte uit die tweede eeu (Strydom, 1994:256), asook 'n nuwe verstaan van die feit dat liturgie en aanbidding sentraal staan in die lewe en werk van die kerk. As gevolg hiervan het groot verskuiwings gekom in die dinamiek en verwagtinge van Christene wat God aanbid. Hierdie verskuiwings het die dryfkrag van die liturgiese beweging van hierdie eeu geword. Die beweging het met groot momentum deur die kerke beweeg omdat dit in al die groot verskillende tradisies (Rooms-Katoliek, Anglikaans, Reformatories en Metodisties) weerklank gevind het (Fenwick \& Spinks, 1995:3). Harling (1995) beweer dat Vaticanum II die Rooms-Katolieke liturgie dramaties nader aan die Protestantse liturgie gebring het en dat dit 'n sterk invloed op liturgiese beskouings vanuit Wes-Europa en die VSA gebring het. Veranderinge op talle ander gebiede is aangevuur deur die veranderinge wat die liturgiese beweging gebring het, sodat met reg beweer kan word dat die liturgiese beweging 'n groter inpak op meer gelowiges se lewens gehad het as die sogenaamde charismatiese beweging (Fenwick \& Spinks, 1995:4).

Wat is die tipiese karaktertrekke van die liturgiese beweging? Nuwe klem val op die eenheid van die Woorddiens en tafeldiens as die twee groot dele van die samekoms van die gemeente. Trouens, die herontdekking van die Vroeë Kerk as model vir die liturgie het in al die kerkgroeperings inslag gevind. Die bedoeling is nie om, soos sommige charismatiese groepe, die liturgie van die Vroeë Kerk te herhaal nie, maar om die beginsels daarvan vir vandag praktyk te maak. In hierdie opsig is die groot wins in alle kerkgroepe die herontdekking van die krag van die Woord in die samekoms (Bradshaw \& Spinks, 1994:21). Verder is dit tekenend van die beweging dat hewig geprotesteer word teen individualisme. Ook is daar 'n nuwe klem op gemeenskapsbeoefening en gemeentedeelname aan die liturgie, omdat die liturgie tog aan die gemeente behoort (Harling, 1995:4, 5). Die eietydse aard van aanbidding is deurslaggewend en dit kom veral na vore in die klem op verstaanbare taal in woord en lied in die samekoms.

'n Belangrike kenmerk van die liturgiese beweging is die wegbeweeg van uniformiteit na pluraliteit binne een tradisie, selfs binne die Rooms-Katolieke tradisie (Koenker, 1954:35). Daarbenewens is daar 'n herontdekking en waardering van mekaar se tradisies en van die krag van transkulturele verryking. Hieronder val die klem, veral in hierdie tyd van oudio-visuele kommunikasie, op simbole en rituele in elkeen van die tradisies. Teenoor die charismatiese beweging, wat van die liturgie 'n ontvlugting van die harde werklikheid maak, is daar in die liturgiese beweging klem op die verkondiging en aanbidding met die oog op sosiaal/maatskaplike betrokkenheid (vgl. Fenwick \& Spinks, 1995:10, 11).

Die vraag is watter invloed hierdie kragtige beweging reeds op lidmate van die hoofstroomkerke het? Die gevaar van die indra van Rooms-Katolieke en 
charismatiese leerstellings deur die beoefening van liturgie kan ontstaan. Die gevaar mag verder wees dat die Skrif op of 'n relatiwistiese of fundamentalistiese wyse gebruik kan word in normebepaling vir liturgiese handelinge. Oordrewe informaliteit, byvoorbeeld deur die soort musiek wat liturgies gebruik word, kan 'n verlies bring van die transendente aspek in die samekoms of 'n verlies van die visie op God. Die gevaar van 'n teenreaksie teen elemente in die liturgiese beweging mag lei na 'n ongesonde na-binne-gekeerdheid en 'n vashou aan tradisies uit die harde formalistiese negentiende en vroeg-twintigste eeu wat ware aanbidding versmoor het (De Klerk, 1998:75).

Daar is positiewe ontwikkelinge in die liturgiese beweging waaroor ons in gereformeerde kringe baie dankbaar kan wees, soos byvoorbeeld die herontdekking van die Woord, die deelname van die gemeente aan die liturgie en die invloed van die liturgie op die lewe van elke dag. Hierdie wêreldwye beweging moet egter wetenskaplik-krities vanuit gereformeerde beginsels beoordeel word en 'n eie bydrae moet tot hierdie lewendige debat gelewer word.

\subsection{Die transformerende krag van die liturgie in die kerkgeskiedenis en in die hedendaagse kerklike lewe}

Die kragtige uitwerking wat die liturgie van die tabernakel en die tempel in die bedeling van die $\mathrm{Ou}$ Testament op die samelewing gehad het, kan nie oorbeklemtoon word nie. Die reformasies van profete en konings is aangevuur deur die heropbou van die tempel en die herstel van die tempeldiens (Vos \& Pieterse, 1997:39). Christus se rigtingwysende uitspraak, naamlik dat God deur die Gees en in waarheid aanbid moet word (Johannes 4:26), het 'n kragtige wending in die liturgiese handelinge van die Christelike kerk gebring (Du Toit, 1993:71). Daar moet in gedagte gehou word dat Christus se uitspraak gemaak is binne die sfeer van die heidense aanbidding van die Samaritane, wie se godsdiens in formalisme opgegaan het.

By deformasie en reformasie was liturgiese kwessies telkens in die brandpunt, byvoorbeeld, in die vierde eeu die deformasie waarin die wegbeweeg van Woorddiens na sakramentalisme en mistisisme kenmerkend was, die reformasie van die sestiende eeu waarin die altaar met die preekstoel (die Woorddiens) vervang is (Brienen, 1987:48), die gemeente weer betrokke geraak het en die kerklied deur die kerkvolk gesing is. Die stryd om die invoer van gesange was die stimulus vir kerklike draaipunte in Nederland en Suid-Afrika gedurende die vorige eeu.

Die transformerende krag van die liturgie word veral in die twintigste eeu geillustreer in die vernuwing wat in die groot Rooms-Katolieke kerklike gemeenskap na Vatikaan II in 1963 gekom het. Hierdie vernuwing is te danke aan drastiese reformasie op die gebied van die liturgie, in besonder die Woorddiens 
(White, 1977:843). Reformatoriese kerke in Suid-Afrika bespreek tans liturgiese vraagstukke wat kragtig ingryp op die lewe en aanbidding van plaaslike gemeentes - vergelyk byvoorbeeld die bespreking oor kindernagmaal (NG Kerk se Sinode in Oktober 1998), die wyse van nagmaalsviering in die Gereformeerde Kerke en die belangrike besluite wat oor die liturgie in 1997 geneem is (Handelinge, 1997:731-768). Dit kan binnekort wendinge in die lewe van kerke meebring.

Die liturgiese toneel vandag is een van dinamiese ontwikkeling, wat die wese van kerkwees raak, want in die liturgie word die lewe van die kerk weerspieël (De Klerk, 1987:1). Ook vanweë die transformerende krag van die liturgie in deformasie en reformasie van die kerk in die kerkgeskiedenis en vandag, vereis hierdie betrokke wetenskap op die gebied van die Praktiese Teologie indringende onderrigleer en navorsing.

\section{3. 'n Eie aanslag: verdieping in ons liturgie}

\subsection{Verdwyning, vernuwing of verdieping?}

König (1998:65) stel te kategories die alternatief: vernuwe of verdwyn. Hy maak die stelling dat kerke binne een kerkverband moet aanvaar dat daar verskillende vorme van aanbidding is en as kerke en lidmate nie vir mekaar ruimte maak om vanuit verskillende tradisies te aanbid nie, sal dit rampspoedig vir die kerkgemeenskap wees: "Ons sal moet ruimte laat vir mekaar anders sal ons stadigaan verdwyn". Vir hom bevat die sogenaamde vernuwingsdienste van die NG Kerk die volgende elemente: 'n aangepaste evangeliese tradisie (vanuit die negentiende eeu) en beperkte Pinkster-charismatiese invloed wat op die basis van 'n Reformatoriese erediens inwerk (König, 1998:83). 'n Ander wyse waarop vernuwing voorgestel word, is om 'n Katoliek-gereformeerde liturgie as alternatiewe diensorde vir die NG Kerk te ontwerp (Strydom, 1994:261). Die standpunt is dat die liturgie sal wen aan diepgang en vitaliteit ten opsigte van feestelikheid, dialoog en deelname van die gemeente. Omdat dit veral oor die diensorde by die Nagmaalsviering gaan, sal gelowiges die liturgies-geestelike betekenis en relevansie van die sakramentsviering opnuut besef. Die volledige uiteensetting van die diensorde is, volgens Strydom self, onomwonde Katoliek ten opsigte van struktuur en ten opsigte van inhoudgewing onweerlegbaar gereformeerd.

Die sterkste motiewe vir die vernuwing van die samekoms van die gemeente is die skerp kritiek wat teen die erediens uitgespreek word - kritiek met die implikasie dat die erediens dood, koud en onpersoonlik, vreemd aan die lewe en werklikheid sou wees. Die erediens het vir baie mense sy sin en betekenis verloor en daarom bly mense van aanbiddingsgeleenthede weg. Positief is vernuwing nodig omdat die wese van die erediens vernuwing vra, omdat die vernuwing van 
die erediens vernuwing in die geloofslewe bring en waar vernuwing uitbly, daar kom die oordeel van God (Barnard, 1988:39-41). Vanuit Rooms-Katolieke hoek stel Van Tongeren (1997:198) die volgende: as die liturgie vernuwe word tot 'n lewende liturgie wat die gelowiges van vandag en môre wil aanspreek en die geleentheid tot ware aanbidding gee, dan kan die liturgie nie net vanuit die verlede gevoed word nie, maar moet dit vorm kry in en vanuit die aktuele konteks van die gelowige. Daarom moet die liturgie blywend vra na vernuwing: Liturgia semper reformanda sit. Die intensie van Vaticanum II om die liturgie by vandag te bring impliseer tegelykertyd om blywend te werk aan die vernuwing van die liturgie.

Die begrip "vernuwing" kan vanuit die Skrif verantwoord word, veral op grond van die werk van die Heilige Gees. Vernuwing is dan die biddende verstaan, belewing, beoefening van gemeenskap met God in Christus, deur die werk van die Heilige Gees, waardeur die liturgie van die samekoms, huisgesin en werkplek voortdurend hervorm en verdiep word. Maar deur die geskiedenis het die begrip 'n negatiewe belading gekry. Calvyn word beskuldig dat hy allerlei nuwighede in die liturgie inbring as hy die woorde van vryspraak en troos in die verootmoedigings- en versoeningsdiens inbring. Hy antwoord dat dit al in die Vroeë Kerk praktyk was (Handelinge, 1997:747); daarom protesteer Calvyn teen die etiket van "vernuwing" (Pasztor, 1988:910). Vernuwing beteken vir baie hedendaagse mense die willekeurige en subjektiewe eksperimentering in die samekoms van die gelowiges. Maar vernuwing is iets wat van binne af moet gebeur deur die Heilige Gees, wat die mens in diens neem in hierdie altyd reformerende werk. Erediensvernuwing word tans te veel vereenselwig met eredienspopularisering (Strydom \& Kellerman, 1992:205). In baie kerke word eredienste vandag bekendgestel as sogenaamde "vernuwingsdienste". Hierdie vernuwingsdienste het skynbaar in sommige plekke meer en in ander minder "sukses", afhangende van waaraan die sukses gemeet word.

Wanneer die 'sukses' van erediensvernuwing (hetsy in terme van beter bywoningsyfers, groter 'lidmaat-tevredenheid' wat betref persoonlike voorkeure, giere, modegrille, ensomeer) in direkte korrelasie gebring word met die menslike inset, kom ons in die gevaar dat mensverering in plaas van Godsverering op die voorgrond tree (Laubscher, 1988:17, 18).

Vanweë die negatiewe belading van vernuwing as menslike willekeur, kan dieselfde vernuwende werk van die Heilige Gees in en deur sy menslike instrumente met verdieping van die samekoms van die gemeente beskryf word. Die Gees bewerk immers ' $n$ dieper besef van die heilige teenwoordigheid van God in die samekoms en daarmee gepaardgaande 'n aanbidding deur die Gees en in waarheid. 


\subsection{Verdieping is riskant}

Omdat die lyne van die teologie in die liturgie saamtrek (Vial, 1998:65), kan nie willekeurig te werk gegaan word met hierdie besondere gemeenskap van God met die mens en - daaruit voortvloeiend - die gemeenskap van die mens met God en gelowiges met mekaar nie. Verdieping in die liturgie hou in dat noukeurig geluister moet word na God in sy Woord, sy stem in die geskiedenis en sy kragtige werk in die hede. Die erediens word al meer gesien as die sentrale dimensie van die totale diens aan God, as die kragbron en rigtinggewende beginsel van die mens se algehele godsdiensbelewenis. Verdieping in die erediens is wesensbelangrik vir die voortdurende hervorming van die kerk en vir die evangelisering van afvalliges (Vorster, 1996:204). Verdieping beteken dus dat die wetenskaplike hom voortdurend voor God moet kan verantwoord.

$\mathrm{Na}$ die kant van die kerklike lewe is dit ook riskant om verdieping te bepleit, want in die beoefening van nadenke oor die liturgie speel die smaak en voorkeure van individue ' $n$ belangrike rol. Die gevaar is dat in kerklike kringe meestal nie prinsipieel besin word nie, maar dat nadenke op subjektiewe voorkeure berus (De Klerk, 1987:3). Te maklik is vashou aan die bestaande 'n soort beginsel wat vanselfsprekend geld, terwyl dit dikwels 'n vashou aan elemente impliseer, wat ontstaan het uit die deformasie van die agtiende en negentiende eeu. In hierdie opsig kan byvoorbeeld verwys word na die oorskatting van die preek ten koste van die Skriflesing en ander elemente van die samekoms van die gemeente. Aan die ander kant word opportunistiese modegiere ongetoets ingevoer om die samekoms meer eietyds en aantrekliker vir mense te maak. Dié neiging het niks met verdieping in die liturgie te doen nie.

"Verdieping" in die samekoms van die gemeente beteken: luister bo alles na die Skrif. Dit hou in dat alles in die samekoms ordelik moet gaan. Hierdie orde is dikwels in die verlede met volgorde verwar. In werklikheid beteken hierdie Skrifgedeelte (1 Kor. 14:39, 40) dat alles in die samekoms in harmonie moet verloop, sodat elke lidmaat 'n funksie vervul en ander hierin in ag neem (Martin, 1984:83). Verder beteken ordelikheid en welvoeglikheid dit wat waarlik opbou en dit kan in die konteks van die Skrifgedeelte aan dié kriteria gemeet word: wat is normaal, behoorlik, fatsoenlik, stylvol, netjies en eietyds (De Klerk, 1987:7477). Om te streef na verdieping moet behalwe 'n prinsipiële luister na die Skrif, ook die gang van die geskiedenis nagevors word (veral die hoofmomente soos gedurende die tweede, sestiende en twintigste eeue). Verder moet toegesien word dat die liturgiese handelinge in harmonie geskied, stylvol en eietyds is. Al hierdie aspekte speel ' $\mathrm{n}$ rol in liturgiese verdieping.

Verdieping van ons liturgie vra 'n fyn onderskeid tussen dit wat wesenlik en dit wat middelmatig is. Calvyn toon aan dat God nie 'n eenvormige bloudruk gegee het van die samekomste en die liturgie daarvan nie. Daar is wel ewige beginsels 
wat vir alle tye geld. Brienen (1987:152) sê dat Calvyn nie die Woord op slaafse, wettiese of fundamentalistiese wyse vir die bepaling van die liturgie aangewend het nie. Hy het 'n oog vir die eietydse en plaaslike omstandighede gehad. Die liturgiese vryheid in die handelinge en volgorde is verankerd in die vryheid in Christus (Brienen, 1987:155). Daarom is dit van wesenlike belang om die eenheid van basiese beginsels ten alle koste te behou en tegelyk nie gewetens te bind ten opsigte van middelmatige sake nie. Calvyn is baie skerp oor die binding van die gewete deur dit wat nie uitdruklike voorskrifte van die Here is nie (Brienen, 1987:157). Die wesenlike in die verdieping van die samekoms van God en sy volk is nie 'n saak van handelinge en plekke in die liturgie nie, maar 'n verhoudingsgemeenskap van God met gelowiges en gelowiges met God en mekaar. Hierin moet wesenlike verdieping plaasvind (Stuart, 1996:221).

\subsection{Verdieping beteken: God is by ons!}

Die teenwoordigheid van God deur sy Gees in die samekoms is die geheim van die dinamiek van die erediens (Fourie \& Müller, 1996:379). Daarom is verdieping in die erediens die dieper besef, belewing en belydenis van God se teenwoordigheid. Die geheim van die lewende teenwoordigheid van Christus (en in Hom God Drieënig) is die werk van die Heilige Gees (Vos \& Pieterse, 1997:104). God kan nie deur enige menslike handeling teenwoordig gemaak word nie; vir sy teenwoordigheid kan net gebid word en dan gelowig vertrou word op sy belofte om in die samekoms te wees. God se magtige teenwoordigheid bepaal die dinamiese handelinge van die gemeente in die samekoms in vier lewensrigtings, in die samekoms en in die liturgie van die lewe: vertikaal vier die gemeente die teenwoordigheid deur God te verheerlik (doksa), horisontaal deur gemeenskap met mekaar te beoefen (koinonia), deur sy getuienis op die wêreld te fokus (marturia) en dan gesamentlik op God, medegelowiges en die wêreld te rig deur diens (diakonia; vgl. Fourie \& Müller, 1996:378).

Dit is opmerklik dat die essensie van ware liturgie, van ware aanbidding juis moet kom uit die opmerking van die buitestander wat in die samekoms van die gemeente kom, naamlik "Waarlik God is hier by julle!"(1 Kor. 14:25). Paulus haal hier aan uit Sagaria 8:23 ("Ons [die ander volke] wil met julle [Israel] saamgaan, want ons het gehoor God is by julle"). Die voorspelling van Sagaria is dat die heidense volke aan die einde van die dae sal erken: God was waarlik onder sy volk. Nou is die verrassende toepassing: deur die werk van die Heilige Gees gebeur dit wat vir die einde voorspel is reeds in die hede. Deur die dinamika van die feestelikheid, gemeenskap, getuienis en diens in die samekoms word die buitestander tot selfondersoek en belydenis gebring: "God is hier en daarom werk sy krag in my!" (vgl. De Klerk, 1987:72-74).

Eers wanneer die liturgiese handelinge die gelowige laat besef en beleef dat God lewend teenwoordig is en daar gemeenskap tussen God en gemeente en gemeente 
en God en gemeente onderling plaasvind, kan van erediens sprake wees (Spoelstra, 1994b:53). Die liturgie moet immers die ruimte skep sodat dinamiese lewensgemeenskap kan plaasvind. Verdieping in die wetenskap van die liturgie moet fokus daarop om erediensdeelnemers en buitestanders te laat besef en te laat beleef dat God kragtig in Christus deur die Heilige Gees teenwoordig is. Spoelstra (1994c:580) beweer dat Gereformeerdes in die Gereformeerde Kerke in Suid-Afrika sedert 1927 hulle te veel oor die erediens as objektiewe verskynsel verantwoord het en te min rekenskap gegee het van die liturgie as handeling waarin God ontmoet word. Daarom sal die natuurlike mens dalk in sy gees drasties moet vernuwe, sodat, al kyk hy volgens gangbare maatstawwe "skeel" of "uit die hoek van sy oog", hy God self kan sien en hoor en in hom voel werk. Dit sal verdieping in die ootmoedige aksie van luister bring, asook verdieping in aanbidding, lofprysing, sondebesef en sondebelydenis, vryspraak, onderlinge gemeenskap en getuienis na buite. ' $n$ Tipiese trek van die formalisme is dat die bewustheid van God se teenwoordigheid deur die Heilige Gees ontbreek (Hattingh, 1988:181).

Die teenwoordigheid van die Here is in die Ou Testament met "die heerlikheid van die Here" beskryf en in die Psalms, as liturgiese liedere, kom hierdie uitdrukking nie minder as 24 keer voor nie (Vos \& Pieterse, 1997:45). God se teenwoordigheid in die tempel was die vertrekpunt van die argitektuur van die tabernakel en tempel. Die versoendeksel van die verbondsark is die sentrale fokuspunt, omdat God daarop troon. Wanneer die hoëpriester uit die ontmoetingspunt gekom het, het die volk God se magtige teenwoordigheid ervaar en van blydskap uitgeroep en op hulle knieë geval (Lev. 9:22-24; vgl. De Klerk, 1987:21). In die Nuwe Testament het Christus die magtige teenwoordigheid van God kom eksegetiseer (Joh. 1:18). God is in Christus persoonlik, lewend en kragtig in die midde van sy gelowiges teenwoordig (Floor, 1982:95). In die geskiedenis was die teenwoordigheid van God deur sy Gees en Woord en sakrament belangrike strydpunte. Hierdie strydpunte word geïmpliseer deur vrae soos die volgende: is Christus teenwoordig en hoe is Hy teenwoordig? Die stryd rondom die Nagmaalsviering van Rooms-Katolieke, Lutherse en Calvinistiese kante is bewyse hiervan.

Vandag is spiritualiteit, ook in die liturgie, weer sterk in die brandpunt (vgl. onder andere Han, 1993:154-159; Kunzler, 1995:121; Schwanda, 1996:116; Kim, 1997:83). Spiritualiteit het te maak met die God van die lewe en die lewe van die gelowige en die samehang van die twee (Von Wonterghem, 1998:91). Spiritualiteit gaan om ons verhouding met God, met mekaar en ons godsdienstige lewe in die wêreld (Vos \& Pieterse, 1997:195). Dit gaan om gemeenskap en die vraag is: hoe moet ons ons samekomste (eredienste) inrig en laat lewe sodat lidmate sal verstaan en ervaar dat God in ons midde is? Die ideaal van 'n coram Deo-lewe - 'n lewe voor die aangesig van God - was 'n baie sterk motief van die 
Reformasie. 'n Mens sou selfs kon sê dat dit die hart van die Reformasie was. En reformasie word vandag gebore waar mense weer die visie kry van 'n dieper, nader en gehoorsamer lewe voor die aangesig van God (Burger, 1995:73). Semper reformanda roep ons altyd weer op om in die krag van die Gees hieraan gestalte te gee. Calvyn het "erediens" en "vrees vir God" byna as sinonieme gebruik. Waar ons God vrees, sal ons liturgie verdieping ondergaan (Bridges, 1998:234).

Die soeke na verdieping in die liturgie moet gepaard gaan met 'n skerp bedag wees op mense wat van verdiepte spiritualiteit 'n teelaarde maak van vreemde fantasieë, van menslike willekeur, relatiwisme, fundamentalisme en geesdrywery (Burger, 1995:75). God se teenwoordigheid kan gesien, gehoor en beleef word deur die middele van Woord, lied, gebed, ensovoorts, maar ook in die minder sigbare innerlike gesindheid van liturg en erediensdeelnemers. Die mens wat op die uiterlike alleen ingestel is, sal God nie met die geloofsoog sien nie. Hulle wat in nederige ootmoed bewus is van God se grootheid sal God se teenwoordigheid ontdek: uit die verwondering wat spreek uit hulle liggaamshouding, sang en oorgawe in aanbidding, uit 'n opregte oop wees voor God, deur God bevry van pretensies en 'n voorgeebestaan, en uit 'n oop gees wat wil hoor, stilbly en stilwees voor God en in gewyde stilte na sy stem luister (Burger, 1995:87, 88).

Dit is die aanslag wat vanuit reformatoriese hoek in die teenswoordige besinning op liturgiese gebied nodig is: ' $n$ verdiepte besef van God is hier by ons - 'n besef wat dié uitwerking moet hê: ons wil by julle wees, want God is by julle!

Twee kort voorbeelde van elemente wat in die samekoms deur hierdie benadering hierdie besef kan versterk, is ten opsigte van die Woorddiens en die verootmoedigings- en versoeningsdiens.

\subsection{Twee voorbeelde: Woorddiens en verootmoedigings- en versoeningsdiens}

Die gesindheid van die liturg en die gemeente dat hulle bewus is van God se teenwoordigheid in die samekoms, dat hulle God self raaksien met die geloofsoog, kom skerp na vore in die Woorddiens (Blancy, 1986:574). Beleef die gemeente die lewende teenwoordigheid van God wat self praat, of is die handeling bloot ' $n$ formalistiese verstandelike kennisname van die geopenbaarde waarheid? Die skeeftrekking kan reeds na vore kom in die eerste gebed. Soms is dit die lang, uitgebreide gebed, waarin die liturg omvattend voorbid, sonder dat God eerste aan die Woord gekom het. Die beskeie epiklese-gebed roep God in ootmoed aan, want die hoorder kan God nie hoor weens sy eie verduisterde verstand nie. Ook kan hy nie die goddelike heerlikheid van God wat praat, ervaar nie (Kunzler, 1995:121). Die verligting van die Gees word gevra om hart en verstand, ja die mens in sy totaliteit oop te maak vir God se lewende Woord. Die 
hoorders moet so verlig wees dat hulle kan besef dat dit die lewende God is wat praat. Op grond van hierdie besef moet die hoorder God se Woord en Homself omhels met 'n blydskap wat van die Heilige Gees kom (Vos \& Pieterse, 1997:245).

Die liturg se aankondiging "ons blaai na Jesaja 53", of "die Skriflesing kom uit ...", of "ons lees uit ...", skep die indruk dat hierdie aksie 'n leeshandeling is, 'n voorlesing, eerder as 'n lewende kommunikasie waarin God regstreeks spreek en die gemeente luister, toeëien en doen. Wanneer die preekteks voor die luister na God in sy Woord aangekondig word, verplaas die prediker die erediensdeelnemers se aandag weg van die krag van die Woord na die preek, wat hiermee die primaat in die Woorddiens verwerf (De Klerk, 1987:165). Die gemeente moet egter besef dat God lewend teenwoordig is en dat Hy in hierdie kommunikatiewe handeling van praat en luister/toeëien besig is om te red, te oordeel, op te bou en af te breek.

Calvyn betrek die luister na God in sy Woord en die verkondiging van die Woord in die prediking aan die een kant, ten nouste met die werking van die Heilige Gees aan die ander kant (Pieterse, 1991:93). Pieterse stel dat in Skrifgetroue prediking nie net die genade van God ontvang word nie, maar God self. Calvyn stel dit dat as God deur die Woord spreek en Hy deur die prediking aan die woord kom, dan daal God self uit die hemel neer en maak ons Christus deelagtig deur die werk van die Heilige Gees. Die getuienis van die Gees bring ons tot gelowige aanvaarding en toeëiening van die Skriflesing as God wat regstreeks praat en die Heilige Gees pas die gepredikte Woord in ons lewens toe. Die Gees is die oorsaak en bewerker van die ontmoeting van die lewende God met die gelowige hoorders deurdat Hy Skriflesing en die gepredikte Woord as instrumente gebruik om lewende gemeenskap te bewerk. So weet ons dat God self ook in die prediking tot ons spreek (Pieterse, 1991:94). In die Woorddiens is God by ons, onder ons: Hy proklameer sy Koninkryk, Hy gee bevryding, Hy vermaan, vertroos en bemoedig dinamies en aktueel, Hy seën en gee beloftes (Van der Ven, 1996:80).

So maklik kan geykte frases wat in die preek gebruik word God se teenwoordigheid rasioneel misken. Dink in hierdie verband aan formulerings soos: "Ons behandel ..."; "Ons kyk na ..."; "Ons dink na oor ...". Voorbeelde in hierdie opsig kan vermeerder word. Die prediker wat self deurdrenk is met die besef van God se teenwoordigheid en getrou die Here se spreke verkondig, sal eerder verklaar: "God verkondig ..."; "Die Heilige Gees leer, vertroos, vermaan ons ...", ens. Gelowige hoorders sal saam met die predikers moet bid: "Laat God ons verander deur ons denke (ook oor Skriflesing en prediking) te vernuwe" (Rom. 12:2).

Die tweede voorbeeld handel oor die aangrypende verootmoedigings- en versoeningsdiens. Die sekerheid dat God persoonlik voor elke gelowige in die 
samekoms staan en ook dat God lewend voor die gemeente as eenheid staan, kom in hierdie liturgiese handeling duidelik na vore. Verdieping in die liturgie is op hierdie punt noodsaaklik. Formalisme in die erediens het ook die volgende simptome: die gemeente se gewete is afgestomp, want hulle reageer nie op die teenwoordigheid van die Heilige God nie, nie op sy oordele nie; daarom verlang hulle nie daarna om sy verlossingsvryspraak te hoor en weer daarvan verseker te word nie. Met 'n oppervlakkige sondebeskouing word daar nie vroeg in die samekoms erns met sondebelydenis gemaak nie (Hattingh, 1988:181).

Hierdie handeling is God se lewende en persoonlike vernuwing van sy verbond. God vernuwe die verbond elke keer wanneer sy volk byeenkom op grond van die feit dat ons sondaars is en steeds weer gesondig het. Sy heiligheid vra hierdie vernuwing. Hoe doen Hy dit? Hy roep sy volk saam en laat hulle in sy teenwoordigheid verskyn en saamkom. Sodra die gemeente in God se teenwoordigheid kom, besef hulle hoe vuil hulle werklik is. Vos haal Luther aan (Vos \& Pieterse, 1997:195) wat hierdie gedagte só stel: hoe meer ons besef God is hier in en om en by ons, hoe beter besef ons hoe vuil en vol smet ons is. Hoe meer ons bewus is van God se heiligheid, hoe meer vrees en heilige eerbied ervaar ons vir God in sy oordeel en genade. En hoe groter en ryker die verrassende troos dan as God self die blye nuus oordra van genade en versoening en vryspraak.

Die hele gemeente moet skuld bely deur saam te bid of saam te sing. Ter wille van die innige gemeenskap wat in die res van die samekoms beleef moet word, moet die handeling van skuldbelydenis so vroeg as moontlik in die samekoms plaasvind. Calvyn het hierdie handeling in Straatsburg (soos dit deur Bucer nagelaat is) as eerste liturgiese handeling in die samekoms behou (Deddens, 1995:495). Hy lê nadruk op die gemeenskaplike skuld van die gemeente as eenheid en keer met die vorm van belydenis, vergewing en verbondsvernuwing deur die wet terug na die gebruik in die vroeë kerk. Die wet (en daarom laat hy die wet sing) het by Calvyn feitlik altyd as verbondsvernuwing en oproep tot dankbaarheid, ná die vryspraak, gedien (Deddens, 1995:525). Vos gee benewens die formules wat in die Handboek vir die erediens van die Nederduitse Gereformeerde Kerk aangedui word, drie ander opsies vir die verootmoedigingsen versoeningsdiens (Vos \& Pieterse, 1997:225-229).

Hoewel die ryke skakering van moontlikhede vir die handeling ontgin moet word deur die geskiedenis na te vors, kan die volgende riglyn gevolg word. Stel die gemeente deur 'n Skrifwoord onder die besef dat hulle in die teenwoordigheid van God is - God wie se heiligheid oorweldig (bv. Jes. 6:1 e.v.). Laat die gemeente deur 'n lied skuld bely of deur 'n belydenis uit die Skrif (bv. Ps. 51:3-7) die skuld hulle eie te maak deur 'n spesifieke Skrifgedeelte saam te lees of aan te hoor. Verklaar dan met God se woorde dat hulle sonde vergewe is ter wille van die verdienste van Christus (bv. 1 Tim. 1:15; Joh. 3:16; Rom. 5:1, 2; 1 Joh. 2:1, 2 ). By die vryspraak moet die vermaning gevoeg word dat elkeen wat volhard in 
die sonde of die vryspraak nie wil toeëien nie, onder die oordeel van God bly. Vernuwe die verbond deur ' $n$ beryming van die wet te sing of die wet aan te hoor. 'n Lied waarmee die gemeente hulle verbind om nuut te lewe, kan die verootmoedigings- en versoeningsdiens afrond.

'n Gemeente wat hierdie handeling van harte doen en ontvang, sal in genade die ryke seën van God se teenwoordigheid in die verdere handelinge van die samekoms in gemeenskap met God kan beleef.

\section{Verdieping as antwoord op huidige aktuele vrae in die liturgie}

Die huidige aktuele vrae in die liturgie behoort nie bloot pragmaties en emosioneel-subjektief beoordeel te word nie, maar moet ook vanuit die wetenskaplike hoek van verdieping beskou word. Vrae soos die missionêre gerigtheid, die transkulturele verryking en simbole en rituele in die liturgie, moet beantwoord word deur te vra of en in watter mate dit meehelp of voortvloei uit die besef: God is hier by ons? Die belydenis van die wese van die samekoms van die gemeente het immers oorspronklik nie uit die mond van gelowiges gekom nie, maar is deur die verwondering van buitestanders ontlok. Hulle is in hulle gewete aangespreek, het tot diepe selfondersoek voor God gekom, die verborge dinge van hulle harte het aan die lig gekom. Ook het hulle op hulle knieë geval, omdat die totale persoon aangespreek is en hulle in God se teenwoordigheid sy mag om te oordeel en te red beleef het. Hulle het God daarop aanbid en daarna openlik getuig, hardop: Waarlik, God is hier by julle! (1 Kor. 14:24, 25).

\subsection{Transkulturele verryking in die liturgie}

In 'n kleiner wordende wêreld is kontak van gelowiges oor kulturele grense vandag die reël, eerder as die uitsondering. Hoe kan hierdie verskynsel tot verdieping in die buig voor God lei? Soms word by groot internasionale byeenkomste na gemeenskaplikheid in die lied gesoek, verby die eie van elke kultuur gegaan (Harling, 1995:27) en gesoek na gemeenskaplike simbole. So byvoorbeeld is by so ' $n$ geleentheid 'n verskeidenheid sade in 'n deursigtige houer geplant. Die groeiende saad dien dan om die groei deur transkulturele verryking te simboliseer. Maar daar is 'n ander benadering waarin die verskeidenheid en die eenheid saam behou word. Dit kom veral na vore in die verskillende liedere in baie tale en gebede in die moedertaal, maar ook in een gemeenskaplike taal of vertalings in tale wat almal kan verstaan (Westermeyer, 1992:301). Liturgie word verryk wanneer gelowiges die grootheid van God in hulle midde besef as hulle sy lof hoor uit die mond van baie volke (Rom. 15:911): "Prys die Here, alle nasies! Loof Hom alle volke!" 
Musiek is in hierdie opsig 'n kragtige middel en 'n gemeente wat hierdie transkulturele verrykingsmoontlikhede verwaarloos, verloor die krag van die inspirasie wat vanuit die eenheid van die kerk deurwerk na die plaaslike gemeente (vgl. Kloppers, 1997:184). Deur te luister en deel te neem aan die geestelike sang van ander kulture, vind kruis-kulturele verryking plaas wat God se eer na die plaaslike gemeente kommunikeer (Gittins, 1995:415). Musiek is 'n spieël wat die lewe van die gemeenskap terugkaats en kan dus aangewend word om doodsheid en formalisme in die liturgie te verander. In Etiopië het die beryming van die "Onse Vader" nuwe betekenis in die inhoud van hierdie gebed en in die aanbidding van God gebring, omdat die woorde voorheen klakkeloos deur mense geprewel is (Balisky, 1997:455).

Kulturele elemente soos musiek, sang, dans en ander kunsvorme eie aan 'n spesifieke land, kan ook bydra om die heerlikheid van God se skepping te reflekteer (Leaver, 1988:329) - ook wanneer dit in aangepaste vorm, volgens die maatstawwe van Gods Woord, geïmplementeer word (Fenwick \& Spinks, 1995:159). In die debat oor die invloed van kultuur op die liturgie en die invloed van liturgie op die kultuur en die kruiskulturele verryking van liturgieë, moet die maatstaf wees: hoe word die raaksien van God se teenwoordigheid gedien? 'n Voorbeeld hiervan is dat in die kultuur van die mense van Suid-Indië blomme en kokosneute na die Hindoe-tempel as geskenke vir die afgode gebring is. Die Christene in hierdie wêrelddeel het aan hierdie gebruike 'n Christelike inhoud gegee: blomme is vir hulle die simbool van God se lewende teenwoordigheid en hulle breek kokosneute om te illustreer hoe Christus met sy opstandingskrag die mag van die sonde gebreek het (Wilson, 1990:59). Aan die ander kant mag heidense praktyke sinkretisties inwerk op die liturgie van Christene. Die liturgie van die African Independent Churches (AIC), byvoorbeeld, word in die opelug en onder bome voltrek, soos in die nie-Christelike tradisie, waar die verering van voorvadergeeste ook in opelug en onder bome geskied. Die dienste van die AIC in die opelug en onder bome laat mense meer tuis voel en die nabyheid van God meer regstreeks beleef as in 'n kerkgebou wat tipies Westers in opset is (Zvanaka, 1997:72).

Obaye (1991:45) toon aan dat daar in die Afrika-godsdienste, sowel as in die Christelike godsdiens, sterk klem is op die alomteenwoordigheid van God. Die viering van sy teenwoordigheid kan godsdiens of erediens (worship) genoem word. Die wyse van verheerliking moet steeds Bybelgetrou bly, maar die spesifieke volksaard kan behoue bly. In Afrika byvoorbeeld kan die aard van die verheerliking eerder Afrika-eie as Asiaties of Euro-Amerikaans wees. Tradisionele Afrika-godsverering impliseer ' $n$ groter mate van jubeling en verheerliking van die teenwoordigheid van geeste. Die Christelike geloof moet hierdie aspek van die erediens nie verwaarloos nie (Obaye, 1991:47). Ook in die AfroAmerikaanse kerke is hierdie fisieke uiting van jubeling meer reël as uitsondering. 
Dit gebeur in die prediking en word beskryf as die "shout" in hierdie samekomste (Noel, 1994:72).

Wie hierdie noue verband tussen kultuur en godsdiens erken, kom tot die konklusie dat God se verheerliking nie net oor kulturele grense gaan nie, maar dat die verering van God deur een kulturele groep verdiep word wanneer daar begrip is vir die uniekheid van die verheerliking van dieselfde God deur verskeie volke.

\subsection{Simbole en rituele}

'n Ander aktuele hedendaagse vraagstuk in die liturgie waarvoor die gereformeerde liturg nie sal kan wegskram nie, is die gebruik van simbole en rituele in die samekoms van die gemeente, asook in die liturgie van die huisgesin en die liturgie van die werkplek. Op die terrein van die wetenskap van die liturgie het daar die afgelope twintig jaar dramatiese ontwikkelinge op hierdie gebied in Frankryk, Kanada, Nederland en veral Duitsland plaasgevind (Kunzler, 1995: 170). Simbole spreek tot die regterhemisfeer van die brein - dié deel wat meer beeldend en kreatief funksioneer en dalk tot ' $\mathrm{n}$ meerdere mate in staat is om iets van God te verstaan as die meer logiese en analitiese kant van ons brein (Burger, 1995:90). Babin (1991:30) toon aan dat almal wat vandag effektief met die hedendaagse Westerse- (en miskien veral Afrika-) mens wil kommunikeer, simbole sal moet insluit. Vandag is daar 'n renaissance van die oor na die oog: kommunikasiekundiges stel dit dat mense $75 \%$ van alle inligting deur hulle oë ontvang.

In Suid-Afrika het die Afrikaanssprekende kerklidmaat talle van sy simbole in 'n kort tyd verloor: 'n republiekvlag, sekere volksfeeste, liedere, name van lughawens, ensovoorts (Vos \& Pieterse, 1997:108). Hierdie en ander faktore het 'n litteken op die gees gelaat en meegebring dat Afrikaanse kerke die neiging toon om in hulleself terug te trek. Hierdie ervaring van pyn en verlies moet ook in die liturgie opgevang word. Die mens lewe in en uit die verwysingskrag van simbole, omdat simbole identiteit en geborgenheid verskaf. Omdat die simbool (soos die Bybel op die preekstoel, die brood en wyn by die Nagmaal) die hele persoon betrek, omdat dit 'n skakel, 'n verbond tussen God en mens in die liturgie simboliseer, daarom is die simbool 'n ervaring van nuwe verhoudinge (Laubscher, 1996:67). "Die kommunikasiekrag van simbole lê daarin opgesluit dat dit na wêrelde verwys wat buite ons sigbare werklikheid bestaan. Simbole funksioneer as vensters wat ons 'n uitsig gee op die onuitspreeklike, die oneindige, die transendente" (Pieterse, 1998:346).

Water is 'n bekende simbool, wat onder andere lewe versimboliseer. Die simbool het meer betekenisse, byvoorbeeld reiniging, soos deur die doop gesimboliseer. In Kanada is water in 'n soort ekumeniese liturgie met sout gemeng en rondgestuur sodat elkeen daaraan kon proe. Die simboliek was die trane van die 
verloregaande wêreld en die trane van berou oor sonde. Deelnemers het na hierdie eenmalige simboliese handeling verklaar dat hulle hulle gebrek aan trane herontdek het en dat daar meermale letterlik trane van skaamte, berou en medelye in hulle lewe moet wees (Harling, 1995:23).

In die beoordeling van hierdie gebeure en die aanwending van simbole, moet die volgende in ag geneem word: in hierdie opsig moet eenvoud en matigheid wees; simbole moenie die mens oorweldig nie, maar dit moet jou help om bewus te raak van die eenvoud en wonder van God se teenwoordigheid by sy kinders (Burger, 1995:90). Simbole mag nooit 'n doel op sigself word nie en dit moet verwys na die heilsdade in en deur Jesus Christus. Simboolkommunikasie moet ons in aanraking bring met die lewende Woord, Jesus Christus (Vos \& Pieterse, 1997: 126). Dit moet ongekunsteld, wel kunstig, maar verstaanbaar en aanvaarbaar vir die smaak en gemoedslewe van die gemeente wees. Dit moet getrou wees aan die kultuur, tradisie en beleweniswêreld van die gemeente. Die mens moet in sy diepste wese ontroer word deur simbole en daarom kan die aanwending van simbole ook 'n estetiese ervaring wees. Pieterse (1998:348) beklemtoon die diepste waarde van simbole:

Die groot waarde van simbole is dat dit die kognitiewe verstaan van die evangelie, wat broodnodig is in ons reformatoriese tradisie, aanvul met ' $n$ emosionele, estetiese en gemoedservaring en verstaan. Dit betrek die hele mens: die kognitiewe, die affektiewe en die konatiewe sye en spreek jou in jou diepste wese aan (in Vos \& Pieterse, 1997:126).

In die totale liggaamlike ervaring in die gereformeerde erediens - deur die liturgiese handelinge en simboliek heen - word die geestelike ontmoeting met God gesmaak deur Woord en Gees.

Sodanige en ander aktuele hedendaagse vrae sal met 'n benadering wat dien om God se teenwoordigheid sterker raak te sien, versigtig, maar vreesloos gehanteer moet word. Hierdie vrae kan nie geïgnoreer word nie, omdat ons ons nie mag indroom in ' $\mathrm{n}$ isolasieparadys waar geen invloede van buite kan kom nie.

\section{Verdieping ten opsigte van die liturgie van die lewe}

Die verdieping in die liturgie van die samekoms vloei oor na die gewone lewe (Bridges, 1998:240). Dit gebeur in die wegstuurseën in die samekoms waardeur die volk van God onder sy seënende hand 'n nuwe tydperk van genade binnegaan. Deur hierdie seën (sommige noem dit verkeerdelik die "slotseën") eindig die verering van God nie, maar word die gemeente weggestuur om die verering in hulle huis en werkplek voort te sit (Handelinge Sinode, 1997:766). Die gemeente moet die wegstuur beaam en die seën aktief "ontvang" - 'n "handeling" wat kan plaasvind deur die "amen" uit te spreek of te sing (Vos \& Pieterse, 1997:256). Die seën versterk nie net die erediensdeelnemer nie, maar 
stel hom verder in staat om die seën met ander te deel. Die wêreld het 'n seënende kerk nodig, want God se kinders moet sy teenwoordigheid in die wêreld vier, sodat die wêreld kan sien dat God in ons leef (Vos \& Pieterse, 1997:257).

Van die wisselwerking tussen die liturgie van die samekoms en die liturgie van die lewe is gepraat in terme van saamkom en uitgaan, ontvang en gee, hoor en verkondig, bid en werk, inasem en uitasem, die sustoliese en diastoliese werking van die pompende hart in die liturgie (Barnard, 1997:292). Die erediens wil juis toerus vir die lewe, vir die daaglikse diens aan God en sy koninkryk, vir lewensheiliging en getuienis aan die wêreld. Die erediens mag nooit 'n ontvlugting uit die wêreld wees nie, mag nie eensydig vergeestelik word nie, maar moet uitstuur in die hier en nou om God te vereer (Strydom, 1994a:205). Dit gaan om God se eer en sy eer moet gesoek word binne die milieu en kragveld van die mens se daaglikse lewe (Vorster, 1996:204).

Calvyn sien die liturgie nie as 'n geïsoleerde gebied nie, maar as oop na die totale lewe van God se kinders in die wêreld. In die gelowige se lewe van elke dag kom veral vier liturgiese momente na vore wat Calvyn só benoem: selfverloëning, gehoorsaamheid aan God se wil, naastediens en die vervulling van ons beroep (Brienen, 1987:175). So hoort, volgens Calvyn se visie, liturgiek en etiek bymekaar, asook die dien van die Here op Sondae in die samekoms en die diens in die week in die huise en by die werk. Vanuit ons daaglikse struikeling en tekorte soek ons die vergewing en vertroosting in die erediens, en die erediens dryf ons tot die heiliging van ons lewe en ons werk. Liturgie moet daartoe dien dat die gelowiges (ook in hulle gesinne en as enkelinge) God en medegelowiges in sy teenwoordigheid ontmoet (De Klerk, 1987:79-95). Die doel van die liturgie is die verering van God, ook deur ons beoefening van 'n daaglikse liturgie in die wêreld (Fenwick \& Spinks, 1995:11).

Op grond van die wisselwerking tussen die liturgie van die samekoms en die liturgie van die huisgesin sal opnuut aan verdieping van die spiritualiteit van die huisgodsdiens en lewe in die huisgesin aandag gegee moet word. Watter eenvoudige en effektiewe simbole kan die gesin aanwend om mekaar van God se teenwoordigheid en regeermag te herinner? Die Statebybel en ander groter Bybels op prominente plekke is in baie huise 'n kragtige simbool van die gesin se nederige gehoorsaamheid aan God se Woord. Verder kan die skoonheid van die natuur, verbeeld deur vars blomme in die somer, of iets eie aan die ander seisoene, simbole van God se genade wees. Maar ook rituele soos om saam om die tafel te sit, om hande te neem by die gebed, om dalk huisgodsdiens vroegoggend op die ouers se bed te hou, het 'n sterk simboliese betekenis en 'n kragtige uitwerking op die gesinslewe. Die gesin kan sy liturgie verryk deur saam in die natuur Bybel te lees en stil voor God te word. Dikwels kry gaste nie blootstelling aan die liturgie van die gesin nie, omdat die gesin sy liturgie opskort as daar gaste is. In Nederland is in 1995 indringende werkswinkels gehou oor die 
liturgie van die huisgesin, waar veral op die gebed van die gesin gekonsentreer is (De Oude, 1995:29-41).

In die werkplek vind talle liturgiese handelinge plaas. Baie gelowiges begin die dag met die luister na God en sy Woord in die kantoor of fabriek of met stilgebed. Soms is dit deel van die kultuur van die maatskappy of inrigting om saam 'n werkliturgie te beoefen. Liturgie spreek egter ook uit die oë, positiewe gesindheid, nederigheid, gehoorsaamheid, eerlikheid, naastediens, ensovoorts van gelowiges wat betrokke is. Hierdie veld is nog nie behoorlik deur wetenskaplikes ontgin nie. Wat in die werkplek en in die samelewing gebeur, is dat die gelowige wat God se teenwoordigheid al sterker besef en al hoe intenser beleef, die wêreld voor God bring (onder andere deur sy gebede), en die Here se genade na die wêreld bring. Liturgie is dus nooit 'n ontvlugting uit die wêreld nie, soos baie selkerke dit implementeer nie, want as liturge bring die gelowiges die wêreld voor die aangesig van God. Ook die invloed van 'n kragtige lewensliturgie op die ekologie kom hiermee in die gesigsveld, nog 'n braakveld wat nagevors behoort te word.

\section{Slot}

Die belang en waarde van liturgie word benadruk deur Karl Barth (aangehaal in Martin (1989: 83)): "Christian worship is the most momentous, the most urgent, the most glorious action that can take place in human life". Want sê hy: "The hart of the christian life is to be found in the act of public worship" (Martin, 1989:85).

\section{Bibliografie}

BABIN, P. 1991. The new era in religious communication. Minneapolis : Fortress Press.

BALISKY, L.W. 1997. Theology in song: Ethiopa's Tesfaye Galliso. Missiology. An International Review, 24(4):447-456.

BARNARD, A.C. 1997. Sondag en Sondagviering. Deel II. Voortrekkerhoogte : Makro Boeke.

BARNARD, A.C. 1988. Vernuwing van die erediens. Praktiese Teologie in Suid-Afrika, 6:2962.

BLANCY, A. 1986. The Bible and the church service. Reformed World, 39(2):566-581.

BRADSHAW, P.F. \& SPINKS, B.D. eds. 1994. Liturgy in dialogue. London : SPCK.

BRIDGES, J. 1998. The joy of fearing God. Colorado Springs : Waterbrook Press.

BRIENEN, T. 1987. De liturgie bij Johannes Calvijn. Zijn publikaties en zijn visies. Kampen : De Groot Goudriaan.

BURGER, C. 1995. Gemeentes in transito. Vernuwingsgeleenthede in 'n oorgangstyd. Kaapstad : Lux Verbi.

DAVIES, J.G. 1986. A new dictionary of liturgy and worship. London : SCM Press.

DEDDENS, K. 1995. Rond de schuldbelijdenis in de liturgie. In die Skriflig, 29(3):491-529.

DE KLERK, B.J. 1987. Die Heilige Gees en die verhouding Skriflesing, prediking en gebed in die erediens. Potchefstroom : PU vir CHO. (Th.D.-proefskrif.)

DE KLERK, W.J. 1998. Die vreemde God en sy mense. Kaapstad : Human \& Rousseau. 
DE OUDE, L. 1995. Bidden in het gezin in de Reformatie. Tijdschrift voor Liturgie, 79(1/2): 29-41.

DU TOIT, A.B. ed. 1993. Guide to the New Testament VI. The Gospel of John. Halfway House : N.G. Kerkboekhandel.

FENWICK, J. \& SPINKS, B. 1995. Worship in transition. The liturgical movement in the twentieth century. New York : Continuum.

FLOOR, L. 1982. De doop met de Heilige Geest. Kampen : Kok.

FOURIE, W.A. \& MÜLLER, B.A. 1996. Liturgies-homiletiese beplanning: die erediens as konteks vir preekbeplanning in die gemeentebouproses. Ned Geref Teologiese Tydskrif, 37(3):375-385.

GITTINS, A.J. 1995. Music and gift-exchange: Steps to the inculturation of the Gospel. Missiology. An International Review, 23(4):410-425.

HAN, C.K. 1993. The pastor and spirituality. Theological Compass, 235:148-164.

HANDELINGE van die Ses-en-veertigste Nasionale Sinode van die Gereformeerde Kerke in Suid-Afrika. 1997. Potchefstroom : Administratiewe Buro van die Gereformeerde Kerke.

HARLING, P. ed. 1995. Worshipping ecumenically. Orders of service from global meetings with suggestions for local use. Geneva : WCC Publications.

HATTINGH, C. 1988. Persoonlike gemeenskap met God as korrektief op formalisme in die godsdiens - 'n pastorale studie. Potchefstroom : PU vir CHO. (Th.M.-verhandeling.)

KIM, H.K. 1997. Preacher and spirituality. A diaconiological study in the light of the Pastoral Epistles. Potchefstroom : PU vir CHO. (Th.M.-dissertation.)

KLOPPERS, E. 1997. Liturgical music: Worship or war? Hervormde Teologiese Studies, 53(1):172-184.

KOENKER, E.B. 1954. The liturgical Renaissance in the Roman Catholic Church. Chicago : University of Chicago Press.

KÖNIG, A. 1998. Vernuwe of verdwyn. Hoe oop is die NG Kerk vir verskillende vorme van aanbidding? Kaapstad : Lux Verbi.

KUNZLER, M. 1995. Die Liturgie der Kirche (AMATECA. Lehrbucher zur katholischen Theologie, Band X). Paderborn : Bonifatius Verlag.

LAMBERTS, J. 1997. Twee belangrijke Duitse handboeken in de liturgiewetenschap. Tijdschrift voor Liturgie, 81(6):442-448.

LAUBSCHER, J. 1996. Die huweliksliturgie. Praktiese Teologie in Suid-Afrika, 11(2):57-68.

LAUBSCHER, J.A. 1988. Wie vernuwe die erediens? Praktiese Teologie in Suid-Afrika, 6:1528.

LEAVER, R.A. 1988. Theological dimensions of mission hymnody: the counterpoint of cult and culture. Worship, 62(4):316-331.

MARTIN, R.P. 1984. The Spirit and the congregation. Studies in 1 Corinthians 12-15. Grand Rapids : Eerdmans.

MARTIN, R.P. 1989. Patterns of worship in New Testament Churches. Journal for the Study of the New Testament, 37:59-85.

NOEL, J.A. 1994. Call and response: The meaning of the moan and significance of the shout in black worship. Reformed Liturgy and Music, 28(2):72-76.

OBAYE, Y.A. 1991. The theology of worship from an African Christian perspective. Ogbomoso Journal of Theology, 6:40-47.

PASZTOR, J. 1988. Calvin and the renewal of the worship of the church. Reformed World, 40(2):910-917.

PIETERSE, H.J.C. 1991. Gemeente en prediking. Pretoria : NG Kerkboekhandel.

PIETERSE, H.J.C. 1998. Die rol van rituele en simbole in die identiteitsvorming van 'n geloofsgemeenskap - 'n gereformeerde perspektief. Skrif en Kerk, 19(2):342-348. 
SCHWANDA, T. 1996. Closing the gap: Recovering the experimental nature of Reformed spirituality. Reformed Review, 49(2):109-125.

SCHUMAN, N.A. \& OSKAMP, P. red. 1998. De weg van de liturgie. Tradities, achtergronden, praktijk. Zoetemeer : Meinema.

SCHUMAN, N.A. 1998a. “... Die weet gehad heeft en geen weet gehad”. Skrif en Kerk, 19(2):373-380.

SCMIDT-LAUBER, H-C. \& BIERITZ, K-H. red. 1995. Handbuch der Liturgie. Liturgiewissenschaft in Theologie und Praxis der Kirche. Leipzig : Evangelische Verlaganstalt.

SHEPHERD, M.H. 1960. The liturgical renewal of the church. New York : OUP.

SPOELSTRA, B. 1994a. Liturgie plotseling in die brandpunt. Praktiese Teologie in SuidAfrika, 9(2):113-126.

SPOELSTRA, B. 1994b. Liturgiese handelinge stel nie vanself ' $n$ erediens as ontmoeting met God daar nie. In die Skriflig, 28(1):37-56.

SPOELSTRA, B. 1994c. Liturgie soos in die GKSA beoefen krities bekyk. In die Skriflig, 28(4):557-580.

STRYDOM, W.M.L. \& KELLERMAN, J.S. 1992. Die funksie van liturgiese sang in gereformeerde erediensvernuwing. Ned Geref Teologiese Tydskrif, 33(2):204-215.

STRYDOM, W.M.L. 1994. 'n Katoliek-gereformeerde (eucharistiese) diensorde vir die Ned Geref Kerk? Ned Geref Teologiese Tydskrif, 35(2):256-268.

STRYDOM, W.M.L. 1994a. Sing nuwe sange nuutgebore. Liturgie en lied. Bloemfontein : UOVS.

STUART, S.S. 1996. A New Testament perspective on worship. The Evangelical Quarterly, 68(3):209-221.

VAN DER VEN, J.A. 1996. Morele conflicten in liturgie en prediking. (In Nel, M. red. Prediking, kommunikasie in konteks. Voortrekkerhoogte : Makro Boeke. p. 74-97.)

VAN TONGEREN, L. 1997. Liturgie in context. De vernieuwing van de liturgie en de voortgang ervan als een continu proces. Tijdschrift voor Liturgie, 81(3):178-198.

VIAL, T. 1998. Friedrich Schleiermacher on the central place of worship in theology. Harvard Theological Review, 91(1):59-73.

VON WONTERGHEM, K. 1998. De Geest die levend maakt. De Heilige Geest en spiritualiteit. Tijdschrift voor Liturgie, 82(1/2):91-102.

VORSTER, J.M. 1996. Vernuwing in die Gereformeerde erediens. In die Skriflig, 30(2):203221.

VOS, C.J.A. \& PIETERSE, H.J.C. 1997. Hoe lieflik in u wonings. Studies in Praktiese Teologie. Pretoria : RGN-Uitgewery.

WESTERMEYER, P. 1992. Beyond 'alternative' and 'traditional' worship. Christian Century, 109(10):300-302.

WHITE, H.F. 1977. Our apostacy in worship. Christian Century, 94:842-845.

WILSON, H.S. 1990. Worship and culture. Reformed World, 41(1):57-62.

ZVANAKA, S. 1997. African Independent Churches in context. Missiology. An International Review, 24(1):69-75. 